\title{
XXXII. On the dying struggle of the dichotomous system
}

\section{W.S. MacLeay Esq. M.A. F.L.S.}

To cite this article: W.S. MacLeay Esq. M.A. F.L.S. (1830) XXXII. On the dying struggle of the dichotomous system, Philosophical Magazine Series 2, 8:45, 200-207, DOI: $10.1080 / 14786443008675405$

To link to this article: http://dx.doi.org/10.1080/14786443008675405

册 Published online: 13 Jul 2009.

Submit your article to this journal $₫$

Џll Article views: 2

Q View related articles $\asymp$ 
were porphyritic, with large crystals of felspar, and others looked like pitchstone, with a mixture of pumice; but from its not breaking in a conchoidal form, I am inclined to think it is an obsidian that has suddenly cooled.

[To be continued.]

XXXII. On the Dying Struggle of the Dichotomous System. By W. S. MacLeay, Esq. M.A. F.L.S. In a Letter to N. A. VIGors, Esq. F.R.S.

[Concluded from p. 140.]

R. FLEMING's late work on British Animals I repeat that I have never seen; but his series of affinity as given in the "Philosophy of Zoology" is as follows:

Vertebrata.

Cephalopoda.

Mollusca.

Tunicata.

Annulosa.

Cirripeda.

Annelida.

Entozoa.

Radiata.

Acrita.

In the Hora Entomologica, however, I have not merely said, but I have proved to demonstration, that by the admission of the Mollusca to a higher rank than the Annulosa, the latter would be so far separated from the Vertebrata as to occasion an unnatural interruption of the series. Dr. Fleming now says that the degradation of the Mollusca is decreed by me, "although not very logically," in these terms; "It follows therefore that though they undoubtedly possess a very complete system of respiration and circulation, the Mollusca are inferior in the scale of nature to the Annulosa." These are indeed my words; but the Doctor took good care not to cite the passage which they follow, because that would have proved the deduction to be strictly logical. He appears to fancy, that, on account of their system of respiration and circulation, the Mollusca are superior to the Annulosa; in other words, that an ascidia and an oyster are superior animals to the bee and the ant! But Annulosa breathe as well or better than any Mollusca, and in my present opinion, founded on late dissections, possess a circulation, although of a most peculiar kind. But if they had no system of circulation whatever, the place assigned by me to the bee would not be altered, as Dr. Fleming would have 
himself seen if he had not mistaken Lamarck's " rapports entre des parties semblables ou analogues" for relations of analogy. Lamarck says in the very passage, "Voici l'ordre d'importance qu'il faut attribuer aux organes particuliers que la nature a employé dans l'organization intérieure des animaux :

“ 1. Les organes de la digestion.

"2. Ceux de la respiration.

" 3. Ceux du mouvement.

"4. Ceux de la génération.

"5. Ceux de sentiment.

"6. Ceux de la circulation."

Hist. Nat. des Anim. sans Vert., vol. i. p. 360.

Now I say, admitting that the organs of circulation in $\mathrm{An}$ nulosa may be, or are, inferior to those of Mollusca, still in the above five other systems of superior importance the former animals are infinitely more perfect in their organization than the latter. So much for Dr. Fleming's judgement of logic; a judgement which enables him also to decide that by thus placing the Mollusca below the Annulosa, I have arbitrarily arranged the animal kingdom into the following five groups:

\section{Acrita. \\ Mollusca. \\ Vertebrata. \\ Annulosa. \\ Radiata.}

I must persist however in asserting that neither the arrangement of these groups, nor the groups themselves, are arbitrary. Both I may say are almost mathematically proved to be natural, since the five groups are distinguished, as I have shown (Hor. Entom. p. 200,) by their five respective nervous systems; and because, as to their arrangement, it certainly requires the possession of remarkable powers of thought to entitle us to suspect that a bee is an inferior animal in nature's scale to an oyster.

The only objections that the critic dares to adduce against the above arrangement of the animal kingdom are two, viz. the relation of affinity between cuttle-fish and chelonial reptiles on the one hand, and between fishes and red-blooded worms on the other. This is indeed scarcely the place for entering upon so vast and pleasing a field of anatomical demonstration; my letter is already too long, but I trust notwithstanding that you, my dear friend, will excuse my trespassing still further on your time by a few remarks on this part of the subject.

There is a certain rule in nature so evident that I never knew it doubted, except by Mr. Bicheno, who tells us that no

N.S. Vol. 8. No. 45. Sept. 1830.

$2 \mathrm{D}$

groups 
groups exist in nature but genera and species; thus differing toto coelo from Dr. Fleming, who by advocating the binary system goes to the other extreme, and states that there is an infinite number of natural groups superior to genus and species. The rule alluded to is, that groups of different degree vary in their distance from each other. It is manifest, for example, in the animal kingdom, that the distinction between two congeneric species does not depend on so important a point of structure as the distinction between two contiguous genera, nor this again on so important a point as the distinction between families; and, to proceed in like manner on, the distinction between two sub-kingdoms like Vertebrata and Mollusca, must be greater than all, because it depends on some most important point of structure. A species is not only nearer to its congener than Vertebrata are to Mollusca; but there exists, although it may be impossible to calculate its exact value, a manifest gradation of intervals between the various two contiguous groups of the same rank, which are intermediate between a species and sub-kingdom. A vertebrated animal, for instance, is marked out not merely by its vertebrated structure; the very circumstance of not being vertebral argues other most important distinctions in the general structure of the animal. A gap therefore occurs between Vertebrata and all the rest of the animal kingdom. Not only Lamarck but all other naturalists have admitted it. How then is there no continuity here? I shall show that there is, and again I say an hiatus is not a saltus. Continuity in gradation of structure cannot exist, as we have seen, without intervals; and the size of these intervals does not lessen the truth of the chain, because some of the links may not yet be discovered. How then, you ask, am I to prove that the chain is continuous? I answer, Simply by ascertaining which animals of one group come the nearest to those of the other. If there be no approximation, if all the animals remain equally distant, then there is no continuity; but if one animal of the one group approaches to the structure of the other, then there is a chain of continuity possessing indeed only one link, but not the less presenting a mode of transition from one form to the other. Thus if the only animal existing between Mammalia and Fishes were one Penguin, it would still be in the path of passage. Bat if a Tortoise existed in addition, the chain wouid be more complete, and if one Frog existed also, the chain would scarcely escape notice. In it there is a regular and obvious gradation of structure, although the chasms remain vast. Nevertheless there is no saltus or leap by nature over one form to another; and Linnæus knew this, although by placing a whale immediately 
diately between the cow and the hawk, he took himself a leap as frolicsome as Dr. Fleming has since taken in placing the Tunicata between the Mollusca and Annulosa, as the link of their immediate connection.

Such being the unequal nature of chasms, and their existence being necessary to form that of a continuous chain of animals, the question now to ask is not whether the transition from Vertebrata to the Invertebrata of Lamarck be imperceptibly gradual (for that, although theoretically supposable, has been shown in nature to be impossible), but whether any animals of the Mollusca approach more than the others to the structure of the Vertebrata, and any of the Vertebrata more than the others to that of the Annulosa. I have already de cided this last question, and proved a number of relations of affinity between Mollusca and Vertebrata, and between Vertcbrata and Annulosa, which cannot, as the Doctor imagines, be relations of analogy, for they want the great characteristic of these last, namely, their parallelism. If any relations exist between Cephalopoda and Chelonial reptiles, they cannot be relations of analogy, and therefore must be relations of affinity. Dr. Fleming indeed gives, as usual, a garbled quotation from a passage that $I$ have cited at length from M. Cuvier, but I will not repeat here what I have sufficiently proved. So far as the mere name goes, the genus Chelys is cephalopod as well as Loligo. I trust that he. will endeavour to become acquainted with these and other genera of the two groups, and that he will compare Messrs. Guthrie's and Holberton's late anatomy of tortoises with that of Cephalopoda by M. Cuvier, or, still better, that he will at length take the scalpel in hand. The genera just mentioned are not indeed the nearest to each other of their respective groups, but enough and more than enough is evident to prove their approximation. If any relations exist between them, as there is no parallelism they cannot be relations of analogy; or even could Dr. F. reduce the numerous relations I have pointed out (Horce Entom. p. 248-261) to parallelism, and thus show them to be relations of analogy, it would only add to our conviction that the two groups are contiguous, for such parallelism characterizes two contiguous circles. So, let Dr. Fleming dichotomize until doomsday,-unless indeed he denies the truth of the anatomical facts I have detailed on this question,-the goal he will infallibly arrive at will be the same, namely that Vertebrata are connected with the Mollusca by means of the Cephalopoda and Chelonian reptiles. But "has the attempt to unite the Vertebrata with the Annulosa been more successful?" No, not more so; but. quite as successful. 
Our critic talks a great deal about lampreys and leeches, about the former having eyes and the latter none, with many more observations of similar novelty and to much the same purpose. He must excuse me, but I really have neither time nor inclination to notice them*. I only entreat him to recollect that the transition from Vertebrata to Annelida is not made directly by the eyed lamprey, but by a blind animal called Myxine glutinosat, of which the last naturalist that has described it says, "Voisins des Lamproies par les Ammocates, auxquels ils ressemblent beaucoup, et avec lesquels ils forment un passage très naturel de la classe des Poissons à celle des Annelides." The whole article, which is by Bory de St. Vincent, in the Dictionnaire Classique d Histoire Naturelle, deserves to be read, as it details the grounds of the above affinity. Cuvier had already pointed out the same self-evident fact; yet here is a writer saying " that he is astonished that any individual who ever made the comparison should have been able to perceive very evident affinities where there existed only a few very remote and insignificant analogies." I repeat it, and $I$ have proved it, that he does not know an affnity from an analogy.

Now the foregoing demonstrated affinities are his chosen points of attack, his fancied mortal stabs. Valeant quantum valere possint, and I find myself still safe on my legs. To be sure the tender-hearted gentleman knows more vulnerable points, but he thinks it is useless to be cruel. "In connecting the other circles, defects equally remarkable and extensive might be pointed out, were it necessary to enlarge." Equally remarkable and equally extensive I trust they would be $-I$ want no better.

He says that the quinarian circle, like the tripod of the Isle of Man, "stabit quocunque jeceris." So far as relates to the stability of the system, no doubt the remark is perfectly correct; but the Doctor is I suspect here awkwardly alluding

- I suspect, however, that Sir Everard Home will scarcely feel obliged to him for citing his authority on a point which has long since been disproved by the celebrated French anatomists MM. Majendie and Desmoulins. His admiration of Sir Everard's discovery of the hermaphroditisms of the lamprey, induced him to institute the genus Homea in his honour; although it ought clearly to be called Gastrobranchus, the original fish described preserving the generic name Myxine given to it by Linnæus. In this way Bloch's very appropriate name would not be lost. It is truly unfortunate that the above denial of any affinity between Pertebrata and Annulosa not only proves our Doctor never to have seen his "Homea," which he only knows by Sir Everard's description, but that even to this day he remains in ignorance of the most important point of its structure.

+ See Hora Entomologica, p. 203. 
to its facility, on which head I can only say that when this worthy has produced to the world a natural group differently divided into five circles, each two connected by parallel analogies, then I will believe him. To do it once, the once of nature is abundantly difficult, and the proof is the slowness with which we are evolving the system.

Only two objections of Dr. Fleming's remain to be considered. The first of these is, that " one set of organs are employed to establish a connection here, and another to establish a connection there." And why not? The white man and the negro are distinguished by their feet; while the Asiatic and African elephants are known from other animals by their trunk. I admit therefore the fact, and yet our system when completed will express the variation of all organs. Will it be believed that I am perhaps one of the first after Lamarck who attempted to prevent the selecting such systems of organs at hazard, and perhaps the very first who prescribed the following rule for their choice? "Like every other solitary character that can possibly be adopted for the groundwork of a zoological system, the mode of generation ought to rise in importance only in inverse proportion to its degree of variation. In a group of animals for instance, where it varies according to the species, it is manifestly of less importance as affording natural characters, than among those groups where it remains less subject to variation." These words prove that although we neglect no characters, yet we have a rule for deciding upon their respective values.

The other objection is stated as follows: "The same means which the quinarians employ to divide a group when a fifth is wanting might enable them to subdivide others." Now the same means will not enable them to subdivide others; for they have remarked in nature that every natural group returns into itself, in other words is a circle, and no group presents to their view more than five such groups of equal degree returning into themselves. Again the Doctor destroys himself by an example. "What," says he, "but the most obvious prejudices could induce Mr. MacLeay to divide Insecta into Mandibulata and Haustellata, and leave entire the Arachnida?" He affords the answer himself, but I scorn to take advantage of his ignorance. He means Arachnida*, and I will now answer his question. Mandibulata and Haustellata do not present one circle, but

* Let Dr. Fleming visit the Collections of the Metropolis; there he will see a variety of forms of Arachnida; or still better, for Arachnida are not easily preserved, let him visit the Torrid Zone, the metropolis of Arachnida, and he will see a continuity of forms as remarkable as in Mandibulata or Haustellata. It is only a week since I discovered a spider with only two eyes and every day produces something new in this class. 
two, therefore they form two natural groups. "Omnis sectio naturalis," says Fries, "circulum per se clausum exhibet." And as the Arachnida, on the other hand, present not two circles but one, therefore they compose one natural group*.

This is the most common shoal upon which naturalists run aground. They forget the necessary and obvious inequality of chasms in different natural groups, and found their own artificial groups upon this most fluctuating of all principles; of which moreover they can never detect, by a mathematical comparison of intervals, the exact value. Instead of this conduct, they ought to look to the only certain principle, the closure of the group by the series having returned into itself. This is the only test of a natural group. From the above expression of Dr. Fleming, one would really think that I had never divided Arachnida, but this is not meant. I certainly have not left it entire, and may possibly have divided it just as be would; and the Doctor merely means, that I have not given the divisions such dignity as he judges, from certain chasms, that they deserve. My object, however, was to express every natural group, and above all to demonstrate the chain of continuity. All the rest, such as the comparative width of Huctuating chasms, is but leather and prunella.

By the by, if much more profound naturalists would attend to the above definition of a natural group, they would not so often flounder about in all the difficulties which necessarily attend the supposition of two determinate numbers. We should not hear them agreeing with Mr. MacLeay, that in most cases five is the natural number, although in some cases there uray be as many as seven. Were they to put their seven groups each to the test of returning into itself, they would find that in fact they compose only five natural ones. The determination of the particular number must no doubt depend on observation; but I have already proved in another place, that, whatever this observed number may be, there is necessarily only one. The other parts of the quinary system, such as the maxim of variation, the distinction of relations of affinity from thase of analogy, and the progression of relations of affiwity in circles, are all truths depending upon each other, as I have shown in the Linnæan Transactions. Grant one, and you arrive at the other.

- If Dr. Fleming understood what he writes about, he would have known that two out of five groups always come nearer to each other than the other three aberrant groups; that Aristotle gave the name of Ptilota to the normal group or centrum in the present case; and that, to use the words of M. Fries, "Centrum abit semper in duas series," which here are Mandibulata and Haustellata. 
Dr. Fleming gives just and due praise to the great naturalists of England, Ray, Willoughby, and Lister, and most properly exalts them above Linnæus; but it is evident, from the mode in which he characterizes their works in contradistinction to those of Linnæus, that he never read them, and consequently that he is, in celebrating them, only a plagiarist from some person who has called his attention to their merits. Let him say who this person is.

If any one thing be more clearly prescribed in Natural History than another, it is perhaps a species. Linnæus has defined species thus: "Species tot sunt quot diversas formas ab initio produxit infinitum Ens; quæ formæ, secundum generationis inditas leges, produxere plures, at sibi semper similes." Our establisher of fixed principles, however, scorns this definition, and favours us with the following new one: "When the similarity between objects is complete, the individuals, however numerous, are regarded by the naturalist as constituting a species." This is certainly a shorter definition than the former; and to say nothing of the difference of the sexes, as the similarity between two objects is never complete, it has the advantage of making as many species as there are individual beings.

His mode of distinguishing the sexes is equally accurate. "In the more perfect animals we shall find that one individual of the species will be drawn by an immaterial tie"- "to unite with another individual in the propagation of its kind. If this selection has taken place in a state of freedom, we may with certainty infer that the two individuals are male and female." Provided this attraction be the certain mode of discovering the sexes, the Doctor may perhaps, on his next spring visit to the ditch that surrounds his glebe, discover a carp or tench to be the female of a frog. As the fact to which I allude is not rare, to be convinced of the affinity, he will, without much difficulty, have the evidence of observation. Insects, I suppose, he considers as less perfect animals, and so falling out of the scope of his definition; else would singular males and females be discovered.

But there is no end to the absurdities of this article, which so singularly ornaments the Quarterly Review. I might run on and investigate his "caterpillar's suckers," his "albuminous skeletons," and his "bisulcated pigs," \&c. \&c.; but I will not, and only pray that the dust I have raised about his ears may lie light on these as well as all his other vagaries.

Believe me ever, my dear Vigors, most truly yours, Havana, March 1, 1830.

W. S. MacLeay. 